\title{
COMPATIBILITY OF FOUR EASTERN CANADIAN WOODS WITH GYPSUM AND GYPSUM-CEMENT BINDERS BY ISOTHERMAL CALORI- METRY
}

\author{
COMPATIBILIDAD DE CUATRO MADERAS DEL ESTE DE CANADÁ \\ CON YESO Y YESO-CEMENTO POR CALORIMETRÍA ISOTÉRMICA
}

\author{
Raúl Espinoza Herrera ${ }^{1}$, Alain Cloutier ${ }^{2}$
}

\begin{abstract}
In order to determine the feasibility of manufacturing wood-gypsum and wood-gypsum-cement particleboards, the hydration reactions of four Eastern Canadian wood species with gypsum and Portland cement were studied. The compatibility of hot water extracted and raw wood particles with both gypsum and a gypsum-Portland cement mixture were determined for jack pine, balsam fir, aspen and white birch by isothermal calorimetry. The four species were found to be compatible and suitable for the manufacturing of inorganic-bonded wood composite boards on the basis of the compatibility factor. The hot water extractive content was low in the four species and did not have a consistent impact on the compatibility factor. Nevertheless, hot water soluble extractives did have an impact on the time required to reach the maximum heat flux, delaying it to undesirable levels particularly in the case of balsam fir mixed with neat gypsum. However, the effect of balsam fir on neat gypsum hydration was markedly reduced by the addition of 30\% Portland cement. Hot water extraction of the wood particles and the addition of Portland cement to the wood-gypsum mixture significantly reduced the time required to reach the maximum heat flux. The gypsum-cement mixture was less sensitive to the inhibitory effect of wood than neat gypsum.
\end{abstract}

Keywords: Wood compatibility, hot-water soluble extractives, isothermal calorimetry, hydration, gypsum, Portland cement.

\section{RESUMEN}

La viabilidad de cuatro especies de madera del este de Canadá para la elaboración de tableros de partículas aglomeradas mezcladas con yeso y con una mezcla de yeso-cemento fue estudiada por calorimetría isotérmica siguiendo las reacciones de hidratación de las mezclas yeso-madera y yesocemento-madera. La compatibilidad fue determinada sobre dos tipos de partículas de madera, unas sometidas a un pre-tratamiento de extracción con agua caliente y otras sin pre-tratamiento. Se utilizaron las siguientes especies: Pinus banksiana, Abies balsamea, Populus tremuloides y Betula papyrifera. De acuerdo al factor de compatibilidad, las cuatro especies fueron consideradas compatibles con el yeso y la mezcla yeso-cemento, siendo aptas para la fabricación de tableros compuestos. El contenido de extractivos solubles en agua caliente fue bajo en las cuatro especies y no influyó en la determinación del factor de compatibilidad. Sin embargo, los extractivos afectaron los tiempos de hidratación y en el caso del Abies balsamea retrasaron la hidratación del yeso a un nivel indeseable. Tanto la adición de $30 \%$ de cemento al yeso como la extracción de las partículas de madera con agua caliente redujeron

${ }^{1} \mathrm{PhD}$ Candidate. Centre de recherche sur le bois.Département des sciences du bois et de la forêt. Université Laval. Québec, QC, Canada ${ }^{2}$ Pofessor. Centre de recherche sur le bois.Département des sciences du bois et de la forêt. Université Laval. Québec, QC, Canada Corresponding author: alain.cloutier@sbf.ulaval.ca Received: 03.07.2008. Accepted: 20.10.2008. 
visiblemente el tiempo requerido para alcanzar el máximo flujo de calor, además de eliminar el efecto causado por el Abies balsamea en la hidratación del yeso. En general, la mezcla yeso-cemento fue menos sensible a los efectos inhibitorios de la madera que el yeso puro.

Palabras claves: Compatibilidad, madera, extractivos, calorimetría isotérmica, hidratación, yeso, cemento Portland.

\section{INTRODUCTION}

Particleboards and fiberboards bonded with synthetic resins are not well suited for some applications in the construction industry. Problems include susceptibility to moisture, fire and biodegradation by fungi and insects if they are not treated with appropriate chemicals. An alternative solution is to use inorganic bonded composites which can be manufactured with wood particles and inorganic binders such as Portland cement, magnesia and gypsum. A typical feature of these boards is that they are made from a high proportion of inorganic binder compared to wood. This increases production costs since magnesia and Portland cement are relatively expensive. Additionally, the use of inorganic binders in high proportion increases board density.

Gypsum is less expensive than Portland cement or magnesia and has a faster hardening time. It is also widely available. However, gypsum is less resistant to moisture than Portland cement. It may be possible to increase the moisture resistance of gypsum by mixing it with Portland cement. Gypsum would allow reducing production costs whereas Portland cement in small proportion would improve strength and moisture resistance of inorganic-bonded wood composite boards. During the hydration reaction, the hardening of calcium sulphate hemihydrate $\left(\mathrm{CaSO}_{4} \cdot 1 / 2 \mathrm{H}_{2} \mathrm{O}\right)$ (the main component of gypsum) is mainly caused by the formation of dihydrate crystals $\left(\mathrm{CaSO}_{4} \cdot 2 \mathrm{H}_{2} \mathrm{O}\right)$. On the other hand, the Portland cement hardening process is mainly due to the formation of silicate and aluminate hydrates (Maya 1974, Kosmatka and Panarese 1992).

The most important limitation for the manufacturing of inorganic-bonded wood composite boards is the highly variable compatibility between wood and the inorganic binder. Several factors can affect this compatibility. For instance, the chemistry and amount of wood water soluble extractives strongly influence compatibility (Hofstrand et al. 1984, Moslemi and Lim 1984 Hachmi and Moslemi 1989, Semple et al. 1999). Species containing more than $7 \%$ of hot water soluble extractives can be considered as incompatible (Hachmi and Moslemi 1990). Extractive compounds can delay hydration of inorganic binders, affecting the morphology and size of the hydrate crystals. As a consequence, they can affect the adhesion of inorganic binders to wood (Ahn and Moslemi 1980, Simatupang et al. 1988, Simatupang et al. 1990). In order to reduce this incompatibility, the hot water extraction of wood and the utilization of chemical additives have been proposed (Moslemi et al. 1983, Zhengtian and Moslemi 1985). Another factor impacting the compatibility of wood with inorganic binders is wood $\mathrm{pH}$. Species with a $\mathrm{pH}$ higher than 4.9 are considered incompatible. On the other hand, species with a pH lower than 3.9 are considered compatible (Hachmi and Moslemi 1990).

The hydration characteristics of inorganic cements have been commonly used to determine their compatibility with wood (Sauvat et al. 1999, Sha et al. 1999, Defo et al. 2004). However, to our knowledge the study of Simatupang et al., (1992) is the only one performed on wood-gypsum compatibility. The effect of the wood extractives of ten tropical species on gypsum hydration was analysed by using a common spark-plug as an electrode to determine the electrical conductivity of plaster. Woodcement compatibility on the basis of the cement hydration characteristics has been widely studied by different methods including setting time (Biblis and Lo 1968), maximum hydration temperature (Tmax) and time to reach it (tmax) (Hofstrand et al. 1984, Moslemi and Lim 1984, Zhengtian and Moslemi 1985, Miller and Moslemi 1991) and the heat released in a specific time (Hachmi and Mosle- 
mi 1989, Hachmi and Moslemi 1990, Hachmi et al. 1990). Differential scanning calorimetry (DSC) is considered as part of the methods based on the heat released during the hydration reaction. It has also been used to determine cement hydration characteristics (Sha et al. 1999). The differential scanning calorimeter is very sensitive to thermal changes during hydration and has the advantage to provide the instantaneous flux of free heat and the total energy of the hydration reactions (Alberto et al. 2000). It has been used to study the compatibility of wood-cement mixtures (Sauvat et al. 1999, Alberto et al. 2000, Defo et al. 2004). However, there is no information available on the compatibility of woodgypsum and wood-gypsum-cement mixtures determined by DSC.

The aim of this study was to analyse the compatibility of jack pine, balsam fir, white birch and aspen wood particles with gypsum and with a mixture of gypsum and Portland cement in order to determine which species are the most suitable for the manufacturing of wood-gypsum and wood-gypsum-cement composite boards. The hydration characteristics of inorganic binders and the influence of hot water soluble extractives on the hydration of these substances were determined.

\section{MATERIALS AND METHODS}

\section{Materials}

The gypsum used for this study was composed of at least $80 \%$ of calcium sulphate hemihydrate $\left(\mathrm{CaSO}_{4} \cdot 1 / 2 \mathrm{H}_{2} \mathrm{O}\right)$ and was provided by BPB Canada Inc., Montreal, Canada. The composition of the type 10 commercial Portland cement (CAN/CSA-A5-98) used in the study is displayed in Table 1. Two common Canadian softwood species: jack pine (Pinus banksiana) and balsam fir (Abies balsamea), and two common Canadian hardwood species: white birch (Betula papyrifera) and aspen (Populus tremuloides) were used in order to determine their compatibility with gypsum and gypsum-Portland cement mixtures. Fresh wood samples of these species were provided by Scierie Leduc, Québec, Canada.

\section{Methods}

\section{Hot Water Extractive Content}

The hot water extractive content was determined according to standard ASTM D1110-84 for freshly sawn wood of the four species studied.

\section{Wood-Gypsum-Cement Mixtures}

Gypsum and Portland cement were mixed in a 70:30 proportion on the basis of dry mass of powders in order to increase moisture resistance of the binder. This proportion was chosen following preliminary tests performed to determine the mixture final density.

Table 1. Chemical composition and hydration products of the type 10

Portland cement used in this study.

\begin{tabular}{lcccc}
\hline \multicolumn{1}{c}{ Chemical name } & Chemical & $\begin{array}{c}\text { Main } \\
\text { compound }\end{array}$ & Hydration product & $\begin{array}{c}\text { Mass proportion } \\
(\%)\end{array}$ \\
\hline Tricalcium silicate & $3 \mathrm{CaO} \cdot \mathrm{SiO}_{2}$ & $\mathrm{C}_{3} \mathrm{~S}$ & $\mathrm{mCaO} \cdot \mathrm{SiO}_{2} \cdot \mathrm{nH}_{2} \mathrm{O}$ & 50 \\
Dicalcium silicate & $2 \mathrm{CaO} \cdot \mathrm{SiO}_{2}$ & $\mathrm{C}_{2} \mathrm{~S}$ & $\mathrm{mCaO} \cdot \mathrm{SiO}_{2} \cdot \mathrm{nH}_{2} \mathrm{O}$ & 25 \\
Tricalcium aluminate & $3 \mathrm{CaO} \cdot \mathrm{Al}_{2} \mathrm{O}_{3}$ & $\mathrm{C}_{3} \mathrm{~A}$ & $4 \mathrm{CaO} \cdot \mathrm{Al}_{2} \mathrm{O}_{3} \cdot 19 \mathrm{H}_{2} \mathrm{O}$ & 12 \\
Tetrecalcium & $4 \mathrm{Ca} \cdot \mathrm{Al}_{2} \mathrm{O}_{3} \cdot \mathrm{Fe}_{2} \mathrm{O}_{3}$ & $\mathrm{C}_{4} \mathrm{AF}$ & $4 \mathrm{CaO} \cdot \mathrm{Al}_{2} \mathrm{O}_{3} \cdot 19 \mathrm{H}_{2} \mathrm{O}$ & 8 \\
aluminoferrrite & & & $\left(\mathrm{Al}_{2} \mathrm{O}_{3}\right.$ partly replaced by $\left.\mathrm{Fe}_{2} \mathrm{O}_{3}\right)$ & \\
Calcium sulfate & $\mathrm{CaSO}_{4} \cdot 2 \mathrm{H}_{2} \mathrm{O}$ & $\mathrm{CSH}_{2}$ & & 3.5 \\
\hline
\end{tabular}


The wood was milled (mill model P558 B from Janette Mfg Co.) and sieved before blending with the inorganic binder and water. The size of the particles was between 0.4 and $0.9 \mathrm{~mm}$. They were dried at room conditions to a moisture content (MC) of about $10 \%$ at the time of testing. The water:inorganic binder ratio was 1:1 based on the mass of materials and the wood:inorganic binder ratio was $0.3: 1$ based on the ovendry mass of wood. The selection of these mixture ratios was based on preliminary hydration tests.

\section{Hydration Tests}

The hydration tests were carried out in a differential scanning calorimeter DSC20 METTLER TOLEDO. The temperature of the calorimeter was constant at $30^{\circ} \mathrm{C}$ throughout the tests. This temperature was used because the calorimeter had no cooling system to maintain the temperature at $23^{\circ} \mathrm{C}$. The DSC electrical signals represented the difference in heat flux in $\mathrm{mW}$ between two gold crucibles, one including the test sample and the other one empty. The exothermic reaction of the sample is visualized as a curve of heat flux against time (Fig. 1).

The mixtures used in the hydration tests are shown in Table 2. Three replications were performed for each combination. Gypsum-water and gypsum-cement-water mixtures were used as controls. Test results were statistically analyzed by analysis of variance. When the F-test indicated a significant difference between means at the 0.05 probability level, a Duncan's multiple range test was performed using the GLM procedure of the SAS statistical analysis system.

\section{Determination of the Hydration Curve Parameters}

The most important characteristics of the hydration curve as obtained by DSC such as the maximum heat flux (MHF) and the time required to reach this maximum, were analysed for all tests (Fig. 1). They were determined using the $\mathrm{STAR}^{\mathrm{e}}$ software from METTLER. The apparatus coupled with a data-acquisition system provided the heat flux generated by the reaction as a function of time and the total specific energy by integration of the heat flux over the tested period.

Table 2. Dry components of the mixtures used in the hydration tests.

\begin{tabular}{|c|c|}
\hline Treatment & Replications \\
\hline Gypsum (control) & 3 \\
\hline Gypsum - cement (control) & 3 \\
\hline Gypsum - jack pine & 3 \\
\hline Gypsum - jack pine $_{(\mathrm{ew})}$ & 3 \\
\hline Gypsum - cement - jack pine & 3 \\
\hline Gypsum - cement - jack pine $_{(\mathrm{ew})}$ & 3 \\
\hline Gypsum - balsam fir & 3 \\
\hline Gypsum - balsam fir ${ }_{(\mathrm{ew})}$ & 3 \\
\hline Gypsum - cement - balsam fir & 3 \\
\hline Gypsum - cement - balsam fir ${ }_{(\mathrm{ew})}$ & 3 \\
\hline Gypsum - aspen & 3 \\
\hline Gypsum - aspen (ew) & 3 \\
\hline Gypsum - cement - aspen & 3 \\
\hline Gypsum - cement - aspen ${ }_{(\mathrm{ew})}$ & 3 \\
\hline Gypsum - white birch & 3 \\
\hline Gypsum - white birch $(\mathrm{ew})$ & 3 \\
\hline Gypsum - cement - white birch & 3 \\
\hline \multirow{2}{*}{$\begin{array}{c}\text { Gypsum - cement }- \text { white birch } \\
\text { Total }\end{array}$} & 3 \\
\hline & 54 \\
\hline
\end{tabular}

ew: extracted wood 


\section{Compatibility Factor}

The compatibility factor $\left(\mathrm{F}_{\mathrm{c}}\right)$ was used in order to classify wood affinity towards the inorganic binders considered in this study. This factor is defined as the ratio between the total energy of the hydration reaction of each treatment with each one of the wood species $\left(Q_{c}\right)$, and the energy of hydration of the neat inorganic binder control treatment $\left(\mathrm{Q}_{\mathrm{p}}\right)$.

$$
\mathrm{F}_{\mathrm{c}}=\frac{\mathrm{Q}_{\mathrm{c}}}{\mathrm{Q}_{\mathrm{p}}} \times 100
$$

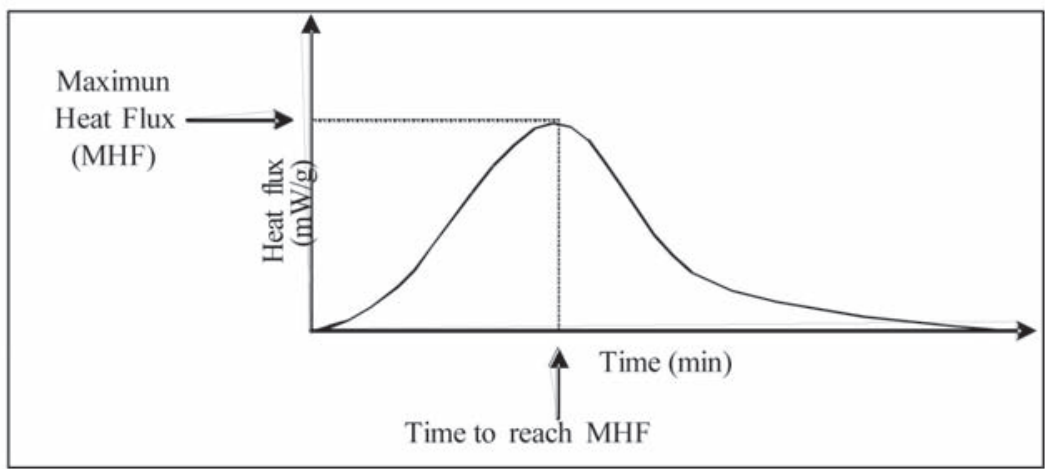

Figure 1. Typical hydration curve as obtained by differential scanning calorimetry.

\section{RESULTS AND DISCUSSION}

\section{Hot Water Extractive Content}

The extractive content of a wood species can provide an indication of its compatibility with inorganic binders. Table 3 shows the hot water soluble extractive content obtained for the species studied. Jack pine had the highest extractive content, significantly higher than for white birch and aspen. No significant differences were found between the hot water extractive content of balsam fir and white birch.

According to Hachmi and Moslemi (1989) who studied the compatibility of wood with cement, species with a hot water soluble extractive content equal or higher than $7 \%$ could be considered as incompatible with inorganic binders. On this basis, the species analysed in this study can be considered as potentially compatible with gypsum and gypsum-cement binders. 
Table 3. Hot-water extractive content for the species studied.

\begin{tabular}{lcc}
\hline Wood species & $\begin{array}{c}\text { Hot-water extractive } \\
\text { content } \\
(\%)\end{array}$ & $\begin{array}{c}\text { Duncan } \\
\text { Grouping }^{\mathbf{a}}\end{array}$ \\
\hline Jack pine & 3.4 & $\mathrm{~A}$ \\
Balsam fir & 2.9 & $\mathrm{AB}$ \\
White birch & 2.2 & $\mathrm{BC}$ \\
Aspen & 2.0 & $\mathrm{C}$ \\
\hline a: Means with the same capital letter are not significantly different $(\mathrm{p}=0.05)$
\end{tabular}

\section{Hydration Curves and Compatibility Factor}

The hydration curves obtained for the three replicates were very similar for all materials analysed. Therefore, three replicates were considered sufficient to determine their hydration characteristics. Hence, all figures presented represent a single curve per material type. The mean results obtained for each material are presented in Tables 4, 5,6 and 7. Wood-gypsum and wood-gypsum-cement mixtures were analysed separately in order to determine the influence of Portland cement on the hydration parameters.

\section{Wood-Gypsum Mixture}

\section{Maximum heat flux (MHF)}

Figures 2 and 3 and the statistical analysis presented in Table 4 show a significant difference between maximum heat fluxes among the different species. Mixing wood with neat gypsum greatly reduced its MHF. Hot water extraction of wood increased the MHF in all wood-gypsum samples (Table 4). Extracted aspen presented a higher MHF than those of two softwoods. Nevertheless, extracted white birch did not present significant differences when compared to extracted softwoods.

\section{Time required to reach $\mathrm{MHF}$}

Table 4 shows the average time required to reach maximum heat flux of the studied samples. The average time required to reach MHF for neat gypsum was 21.3 minutes. The time for the raw woodgypsum mixtures was between 20.0 and 23.3 min except for balsam fir with an average period of 74.1 min.

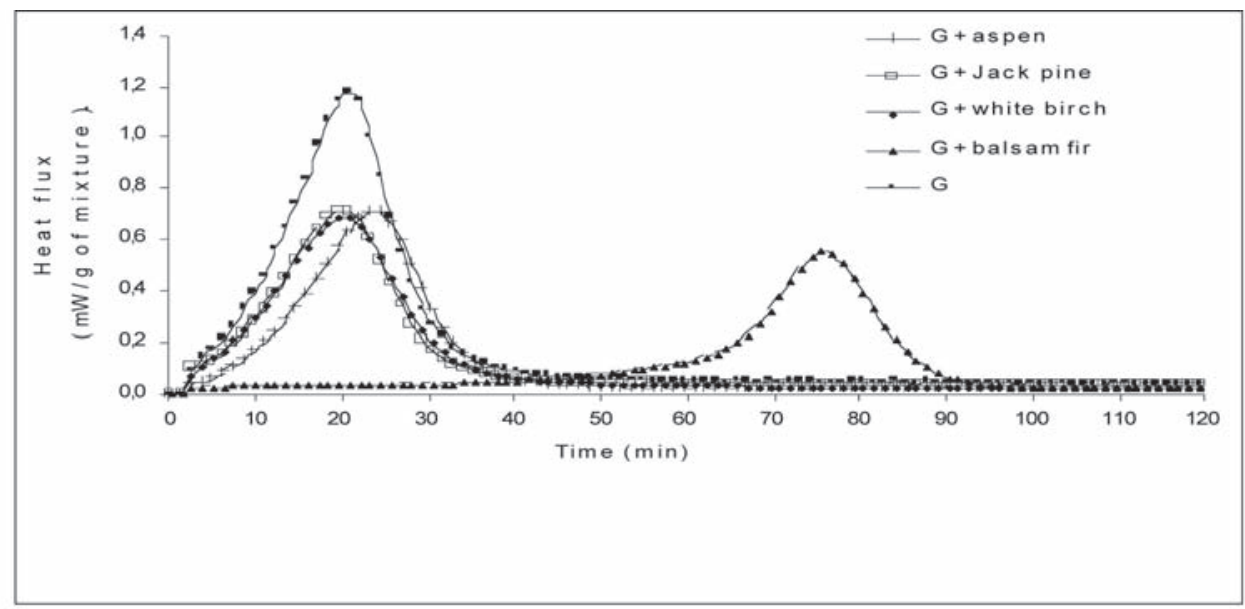

Figure 2. Hydration curves for neat gypsum and wood - gypsum mixtures. Each curve represents the results obtained for one sample. 


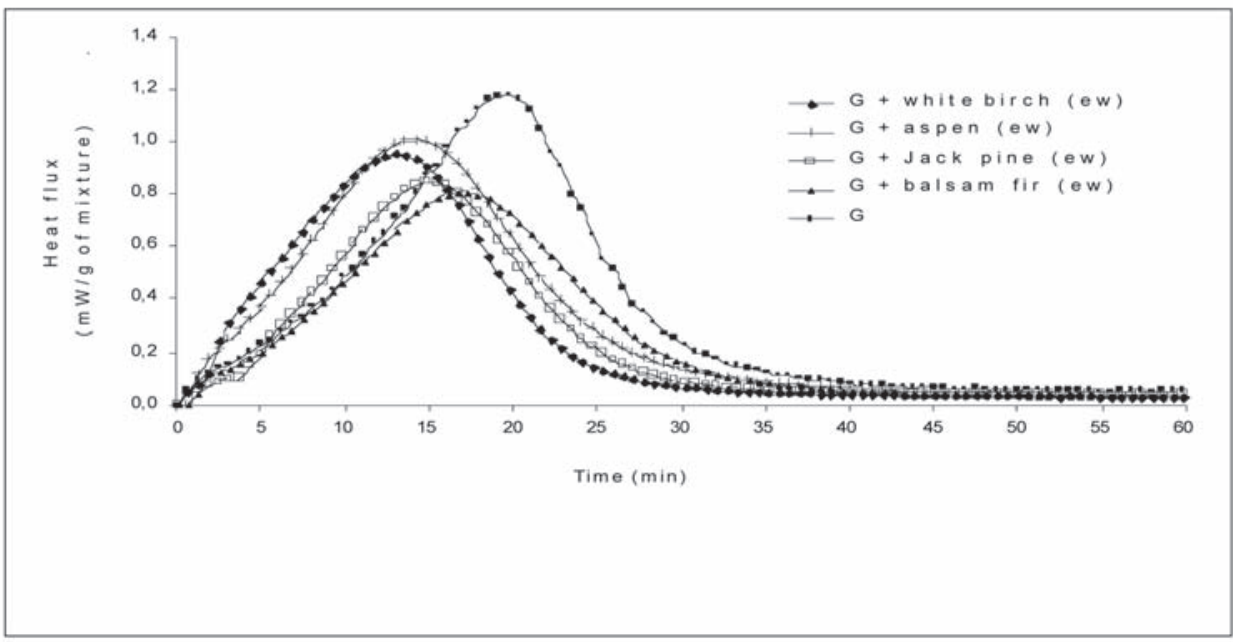

Figure 3. Hydration curves of neat gypsum and hot-water extracted wood -gypsum mixtures. Each curve represents the results obtained for one sample.

Table 4. Maximum heat flux and time to reach MHF of the wood-gypsum mixtures studied.

\begin{tabular}{|c|c|c|c|c|c|}
\hline \multicolumn{3}{|c|}{ Maximum heat flux } & \multicolumn{3}{|c|}{ Time to reach MHF } \\
\hline Treatment & $\begin{array}{c}\text { Mean MHF } \\
(\mathrm{mW} / \mathrm{g})\end{array}$ & $\begin{array}{c}\text { Duncan } \\
\text { Grouping }\end{array}$ & Treatment & $\begin{array}{l}\text { Mean time } \\
\text { (min) }\end{array}$ & $\begin{array}{c}\text { Duncan } \\
\text { Grouping }\end{array}$ \\
\hline $\mathrm{GC}$ & 2.4 & A & $\mathrm{GC}+$ jack pine & 19.3 & $\mathrm{~A}$ \\
\hline $\mathrm{GC}+\operatorname{aspen}_{(\mathrm{ew})}$ & 1.1 & B & $\mathrm{GC}+$ balsam fir & 16.3 & B \\
\hline $\mathrm{GC}+$ white birch $_{(\mathrm{ew})}$ & 1.0 & B & $\mathrm{GC}+$ white birch & 10.3 & $\mathrm{C}$ \\
\hline $\mathrm{GC}+$ aspen & 1.0 & B & $\mathrm{GC}+$ jack pine ${ }_{(\mathrm{ew})}$ & 8.7 & $\mathrm{CD}$ \\
\hline $\mathrm{GC}+$ balsam fir ${ }_{(\mathrm{ew})}$ & 0.7 & $\mathrm{~B} \mathrm{C}$ & $\mathrm{GC}+$ aspen & 8.3 & D \\
\hline $\mathrm{GC}+$ jack pine ${ }_{(\mathrm{ew})}$ & 0.7 & B C & $\mathrm{GC}+$ balsam fir $(\mathrm{ew})$ & 7.0 & DE \\
\hline $\mathrm{GC}+$ white birch & 0.7 & B C & $\mathrm{GC}+$ white birch $_{(\mathrm{ew})}$ & 6.3 & E \\
\hline $\mathrm{GC}+$ balsam fir & 0.7 & B C & $\mathrm{GC}+\operatorname{aspen}(\mathrm{ew})$ & 6.0 & $\mathrm{E}$ \\
\hline $\mathrm{GC}+$ jack pine & 0.5 & $\mathrm{C}$ & GC & 3.3 & $\mathrm{~F}$ \\
\hline
\end{tabular}

\footnotetext{
a: Means with the same capital letter are not significantly different $(\mathrm{p}=0.05)$

ew: Hot-water extracted wood

G: Gypsum
}

Hot water extraction decreased significantly the time required to reach MHF for balsam fir and aspen but not for jack pine and white birch (Fig. 3 and Table 4). Interestingly, the time required to reach MHF for balsam fir-gypsum hydration dropped from $74.1 \mathrm{~min}$ to $17.3 \mathrm{~min}$ after hot water extraction (Table 4).These results clearly demonstrate that hot water soluble extractives of balsam fir have a significant influence on gypsum hydration, despite the fact that the extractive content was lower than $7 \%$. According to Hachmi and Moslemi (1989) some species such as Acacia mollissima have a low extractive content but are incompatible with inorganic binders. This indicates that the chemical composition of the extractives can also determine wood compatibility with inorganic binders. As can be observed in Table 3, the extractive content of balsam fir is not different than that of white birch and jack pine. However, the impact of balsam fir hot water extractives on the time to reach MHF is much more significant. This suggests that this effect is mainly linked with the chemical composition of the extractives and not only with their quantity.

Other authors have also found that gypsum hydration can be delayed by hot water soluble extractives, especially by phenolic compounds and free amino acids (Simatupang et al. 1988). Unfortunately, the composition and amount of hot water soluble extractives have been only studied for the wood of 
Abies sibirica and Abies sachalinensis (Ozawa and Sasaya 1988, Castro et al. 1996) while comprehensive data is lacking for Abies balsamea. A recent study shows that the hot water soluble extractives in balsam fir stem wood are lignans, oligolignans, sugars and sugar alcohols (Willför et al. 2004). According to this study, lignans are the most important hot-water soluble extractives. They occur in free form in stem wood of balsam fir and are easily extracted with polar solvents. Liovil is the most important lignan present in balsam fir stem wood, whereas lariciresinol can be obtained from the knots (Willför et al.2004). On the basis of the chemical characterisation of this species, lignans could be linked with the delay of gypsum hydration. However, further studies using pure lignans are required in order to determine if these chemical phenolic substances are responsible for the long delay of gypsum hydration.

\section{Compatibility factor $(\boldsymbol{F c})$}

The results presented in Table 5 show significant differences between the compatibility factors of the species studied with gypsum. Neat gypsum released an amount of heat of $41.8 \mathrm{~J} / \mathrm{g}$. It was used as a reference to determine $F_{c}$ values of the different species studied. The Duncan test results indicate that neat gypsum and the aspen - gypsum mixture $\mathrm{F}_{\mathrm{c}}$ values were not significantly different. All other woodgypsum mixtures were significantly lower than neat gypsum. However, they were generally compatible with gypsum with $\mathrm{F}_{\mathrm{c}}$ values between 75 and $84 \%$.

Statistical analysis of the $F_{c}$ results obtained for raw wood - gypsum and extracted wood - gypsum samples did not show significant differences. Therefore, hot water soluble extractives did not affect the compatibility factor of these species.

Table 5. Energy of hydration and wood species classification based on the compatibility factor.

\begin{tabular}{|c|c|c|c|}
\hline Treatment & $\begin{array}{c}\text { Energy of hydration } \\
(\mathrm{J} / \mathrm{g})\end{array}$ & $\begin{array}{l}F_{C} \\
(\%) \\
\end{array}$ & $\begin{array}{c}\text { Duncan } \\
\text { Grouping }\end{array}$ \\
\hline G & 41.8 & 100 & $\mathrm{~A}$ \\
\hline $\mathrm{G}+$ aspen & 37.9 & 91 & $\mathrm{AB}$ \\
\hline $\mathrm{G}+$ jack pine & 34.9 & 84 & $\mathrm{BC}$ \\
\hline $\mathrm{G}+$ white birch & 33.7 & 81 & BC \\
\hline $\mathrm{G}+\operatorname{aspen}_{(\mathrm{ew})}$ & 33.4 & 80 & $\mathrm{BC}$ \\
\hline $\mathrm{G}+$ jack pine $_{(\mathrm{ew})}$ & 33.0 & 79 & $\mathrm{BC}$ \\
\hline $\mathrm{G}+$ balsam fir $(\mathrm{ew})$ & 32.9 & 79 & $\mathrm{BC}$ \\
\hline $\mathrm{G}+$ balsam fir & 32.8 & 78 & $\mathrm{BC}$ \\
\hline $\mathrm{G}+$ white birch $_{(\mathrm{ew})}$ & 31.5 & 75 & $\mathrm{C}$ \\
\hline
\end{tabular}

a: Means with the same capital letter are not significantly different $(\mathrm{p}=0.05)$

ew : Hot-water extracted wood

G: Gypsum

\section{Wood-Gypsum-Cement Mixture}

Maximum heat flux (MHF)

The results presented in Figs. 4 and 5 and Table 6 show significant differences between the MHF of gypsum-cement and those of the wood-gypsum-cement mixtures. Hot water extraction did not significantly improve MHF of the wood-gypsum-cement mixtures. Raw wood-gypsum-cement mixtures presented significant differences in MHF only in the case of aspen and jack pine. There were no significant differences in the MHF of extracted wood samples. Clearly, hot water soluble extractives are responsible for the differences between aspen and jack pine since that difference vanished for hot water extracted jack pine. 


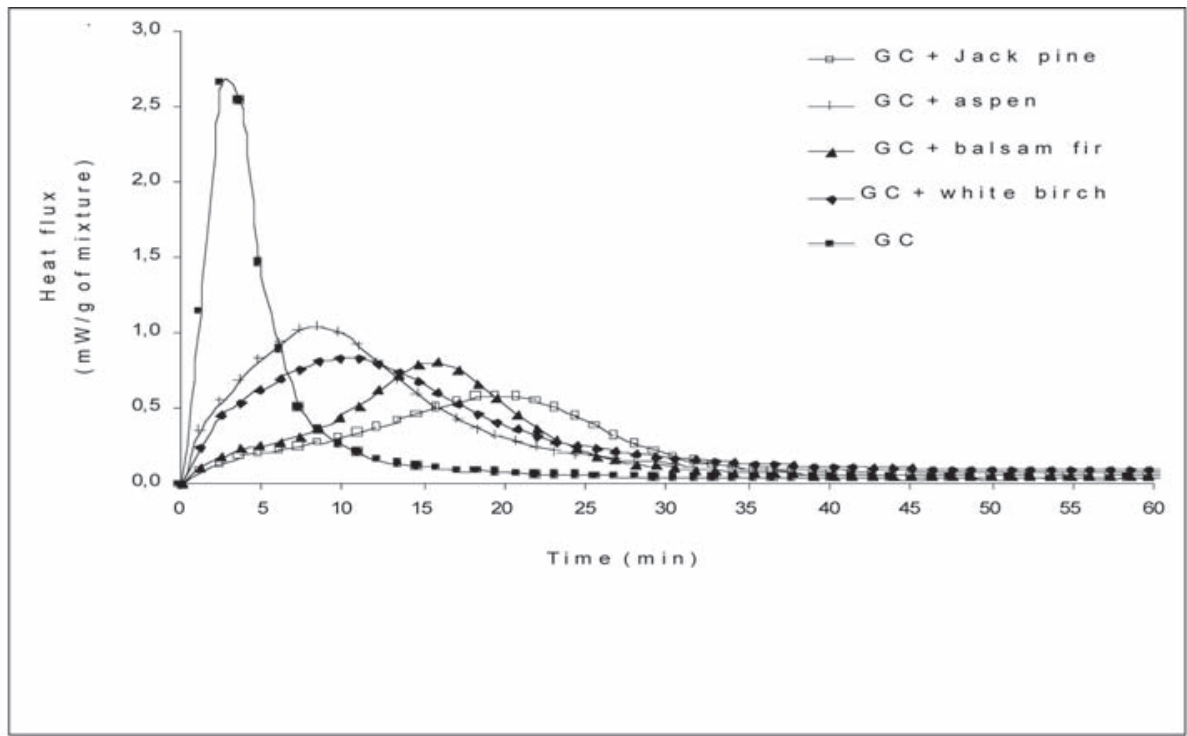

Figure 4. Hydration curves for gypsum-cement $(\mathrm{GC})$ and wood-GC mixtures.

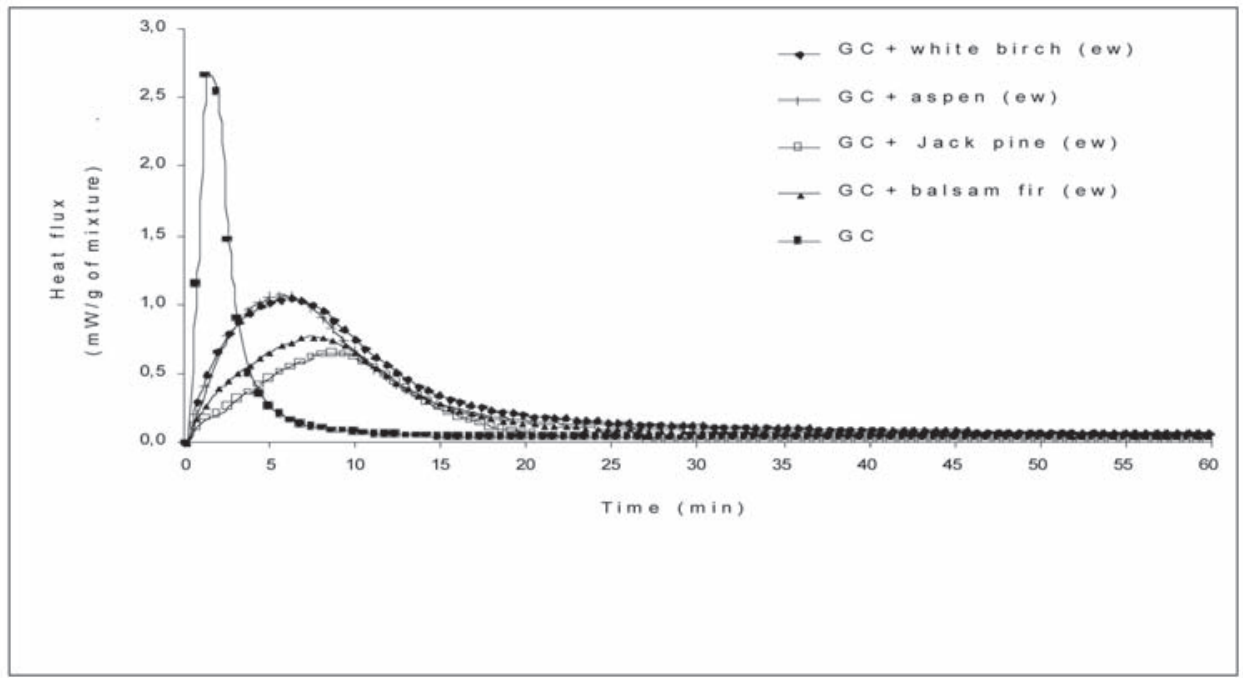

Figure 5. Hydration curves for gypsum-cement (GC) and extracted wood-GC mixtures. 
Table 6. Maximum heat flux and time to reach MHF of the wood-gypsum-cement mixtures studied.

\begin{tabular}{|c|c|c|c|}
\hline Treatment & $\begin{array}{c}\text { Mean energy of } \\
\text { hydration } \\
(\mathrm{J} / \mathrm{g})\end{array}$ & $\begin{array}{l}\mathrm{F}_{\mathrm{C}} \\
(\%)\end{array}$ & $\begin{array}{c}\text { Duncan } \\
\text { Grouping }\end{array}$ \\
\hline GC + white birch & 31.6 & 100 & A \\
\hline GC & 31.5 & 100 & A \\
\hline $\mathrm{GC}+$ aspen & 29.1 & 92 & A \\
\hline $\mathrm{GC}+$ jack pine ${ }_{(\mathrm{ew})}$ & 24.1 & 77 & B \\
\hline $\mathrm{GC}+$ white birch $_{(\mathrm{ew})}$ & 23.3 & 74 & B \\
\hline $\mathrm{GC}+$ balsam fir $(\mathrm{ew})$ & 21.5 & 68 & B \\
\hline $\mathrm{GC}+$ balsam fir & 20.5 & 65 & $\mathrm{BC}$ \\
\hline $\mathrm{GC}+\operatorname{aspen}_{(\mathrm{ew})}$ & 19.6 & 62 & $\mathrm{BC}$ \\
\hline $\mathrm{GC}+$ jack pine & 15.7 & 50 & $\mathrm{C}$ \\
\hline
\end{tabular}

a: Means with the same capital letter are not significantly different $(\mathrm{p}=0.05)$ ew: Hot-water extracted wood

GC: Gypsum-cement

\section{Time required to reach $\mathrm{MHF}$}

Table 6 shows the results obtained for the average time required to reach MHF of the gypsumcement and wood-gypsum-cement mixtures. The average time for the gypsum-cement sample was 3.3 min. When gypsum-cement samples were mixed with both raw wood and extracted wood, the time to reach MHF increased in both cases. However, the raw wood mixtures required a longer time to reach MHF than extracted wood mixtures. The addition of Portland cement to the wood-gypsum mixtures caused an acceleration of the hydration reaction, decreasing significantly the time required to reach MHF as compared to those obtained for wood-gypsum mixtures (Table 4). Also, differences generated by balsam fir hot water soluble extractives in the case of the wood-gypsum mixtures (Table 4) were reduced by the addition of Portland cement.

Hardwoods generally have a lower compatibility with cement than softwoods, partly due to the inhibitory properties of hydrolyzable hemicellulose xylans and other extractives present in hardwoods (Wei et al. 2000, Miller and Moslemi 1991). However, as observed in Fig. 4 and Table 6, the time required to reach MHF was delayed more significantly by the two softwood species than by the hardwood species when Portland cement was added to the wood-gypsum mixture. All species showed significant differences in MHF and jack pine was the species that delayed the time required to reach MHF more significantly. No significant differences in time to reach MHF were found between extracted balsam fir, white birch and aspen. Extracted jack pine did not present a significant difference in time to reach MHF with extracted balsam fir. However, it was significantly different than extracted white birch and aspen.

\section{Compatibility factor}

Table 7 shows the results obtained for the compatibility factor of the species studied with gypsumcement. Significant differences were found between the $\mathrm{F}_{\mathrm{c}}$ values obtained. The gypsum-cement mixture released an amount of heat of $31.5 \mathrm{~J} / \mathrm{g}$ which was used as a reference to calculate the $\mathrm{F}_{\mathrm{c}}$ values. The Duncan test indicated that there were no significant differences between the $F_{c}$ of gypsum-cement mixture and that of raw white birch and aspen. However, gypsum-cement mixture $\mathrm{F}_{\mathrm{c}}$ showed significant differences when compared with that of jack pine and balsam fir.

Hot water extraction of jack pine improved its compatibility. On the contrary, $\mathrm{F}_{\mathrm{c}}$ decreased for hot water extracted hardwoods. Therefore, it could be hypothesised that hot water soluble extractives of white birch and aspen resulted in longer hydration time. A longer hydration time would allow the formation of higher amounts of hydration products and therefore higher energy of hydration which in turn resulted in higher $\mathrm{F}_{\mathrm{c}}$ values for the gypsum-cement mixture. 
Table 7. Wood species classification based on the compatibility factor $\mathrm{F}_{\mathrm{C}}$.

\begin{tabular}{lccc}
\hline \multicolumn{1}{c}{ Treatment } & $\begin{array}{c}\text { Mean energy of } \\
\text { hydration } \\
(\mathrm{J} / \mathrm{g})\end{array}$ & $\begin{array}{c}\mathrm{F}_{\mathrm{C}} \\
(\%)\end{array}$ & $\begin{array}{c}\text { Duncan } \\
\text { Grouping }^{\mathrm{a}}\end{array}$ \\
\hline $\mathrm{GC}+$ white birch & 31.6 & 100 & $\mathrm{~A}$ \\
$\mathrm{GC}$ & 31.5 & 100 & $\mathrm{~A}$ \\
$\mathrm{GC}+$ aspen & 29.1 & 92 & $\mathrm{~A}$ \\
$\mathrm{GC}+$ jack pine $_{(\mathrm{ew})}$ & 24.1 & 77 & $\mathrm{~B}$ \\
$\mathrm{GC}+$ white birch $_{(\mathrm{ew})}$ & 23.3 & 74 & $\mathrm{~B}$ \\
$\mathrm{GC}+$ balsam fir $_{(\mathrm{ew})}$ & 21.5 & 68 & $\mathrm{~B}$ \\
$\mathrm{GC}+$ balsam fir $^{\mathrm{GC}}+$ aspen $_{(\mathrm{ew})}$ & 20.5 & 65 & $\mathrm{BC}$ \\
$\mathrm{GC}^{\mathrm{G} \text { jack pine }}$ & 19.6 & 62 & $\mathrm{BC}$ \\
\hline
\end{tabular}

a: Means with the same capital letter are not significantly different $(\mathrm{p}=0.05)$ ew: Hot-water extracted wood

GC: Gypsum-cement

\section{Influence of inorganic binders on compatibility with wood}

At present time, no studies have been found on the compatibility of wood-gypsum mixtures and wood-gypsum-cement mixtures determined by the DSC method. Defo et al. (2004) used DSC to determine the compatibility of the same species with neat Portland cement. The results obtained by these authors contrasted with our results. In the present work, white birch showed the highest $\mathrm{F}_{\mathrm{c}}$ and jack pine presented the lowest $F_{c}$ for the gypsum-cement mixture. When these species were solely mixed with neat Portland cement by Defo et al. (2004), jack pine was the most compatible species $\left(\mathrm{F}_{\mathrm{c}}=48\right.$ $\%)$ and white birch was the least compatible $\left(\mathrm{F}_{\mathrm{c}}=17 \%\right)$. Balsam fir and aspen presented compatibility factors of $43 \%$ and $34 \%$ respectively when mixed with neat Portland cement. Clearly, compatibility not only depends on the wood species but also on the inorganic binder used. One point to notice is that the addition of Portland cement to the wood-gypsum mixture reduced very significantly the time to reach MHF.

All species studied in this work had higher compatibility factor with neat gypsum than with neat Portland cement as reported by Defo et al. (2004). However, when gypsum was mixed with Portland cement the compatibility factor of the species changed. Thus, jack pine and balsam fir had higher compatibility factor with gypsum than with gypsum-cement, whereas white birch presented a higher compatibility factor with gypsum-cement than with neat gypsum. Aspen compatibility factor was similar with gypsum and gypsum-cement. 


\section{CONCLUSIONS}

Most of the four Eastern Canadian wood species analysed in this work could be considered as compatible with gypsum and gypsum-cement binders according to their compatibility factor values. It was shown that balsam fir significantly delayed gypsum hydration but it could be used if subjected to a hot water extraction pre-treatment. In terms of compatibility factor the two hardwoods studied, white birch and aspen showed the higher compatibility factor when mixed to gypsum and Portland cement and a high compatibility factor when mixed with neat gypsum.

Hot-water extraction had a very significant effect on the reduction of the time required to reach the maximum heat flux but not on compatibility factor in the case of wood-gypsum mixtures. The time required to reach the maximum heat flux provides important information for the determination of mat forming and pressing time during inorganic-bonded wood composite boards manufacturing.

The addition of Portland cement to the gypsum mixture caused the acceleration of the hydration reaction as shown by the shorter time required to reach maximum heat flux. Thus, the delay of neat gypsum hydration caused by balsam fir was largely eliminated when gypsum was mixed with $30 \%$ Portland cement. Overall, the gypsum-cement mixture seems to be less sensitive to the inhibitory effects of wood than neat gypsum.

The removal of hot-water soluble extractives had no clear influence on the compatibility factor in wood-gypsum-cement mixtures. It decreased the compatibility factor for hardwoods-gypsum-cement mixtures whereas it increased this parameter for the jack pine-gypsum-cement mixture. No influence of hot-water soluble extractives on the compatibility factor was observed for balsam fir.

\section{ACKNOWLEDGEMENTS}

The authors are grateful to the National Council for Science and Technology (CONACYT) of Mexico for a Ph.D. scholarship to the first author. We also thank BPB Canada Inc. and Scierie Leduc for providing the raw gypsum and wood necessary for this study.

\section{REFERENCES}

Ahn, W.Y.; Moslemi, A.A. 1980. SEM examination of wood-portland cement bonds. Wood Sci. 13(2): 77-82.

Alberto, M.M.; Mougel, E.; Zoulalian, A. 2000. Compatibility of some tropical hardwoods species with Portland cement using isothermal calorimetry. Forest Prod. J. 50(9): 83-88.

ASTM. 1984. Standard Test Methods for Water Solubility of Wood. West Conshohocken, Pa.: American Society for Testing and Materials. D1110-84.

Biblis, E.J.; Lo, C.F. 1968. Effect on the setting of southern pine-cement mixtures. Forest Prod. J. 18(8): 28-34.

CAN/CSA . 1998. National Standars of Canada. Specification of cements. CAN/CSA-A5-98

Castro, M.A.; Gordaliza, M.; Miguel Del Corral, J.M.; San Feliciano, A. 1996. The distribution of lignanoids in the order Coniferae. Phytochemistry 41 (4): 995-1011. 
Defo, M.; Cloutier, A.; Riedl, B. 2004. Wood-cement compatibility of some Eastern Canadian woods by isothermal calorimetry. Forest Prod. J. 54 (10): 49-56.

Hachmi, M.; Moslemi, A.A. 1989. Correlation between wood-cement compatibility and wood extractives. Forest Prod. J. 39(6): 55-58.

Hachmi, M.; Moslemi, A.A. 1990. Effect of wood pH and buffering capacity on wood - cement compatibility. Holzforschung 44(6): 425-430.

Hachmi, M.; Moslemi, A.A.; Campbell, A.G. 1990. A new technique to classify the compatibility of wood with cement. Wood Sci. Technol. 24(4):345-354.

Hofstrand, A.D.; Moslemi, A.A; Garcia, J.F. 1984. Curing characteristics of wood particles from nine northern Rocky mountain species mixes with Portland cement. Forest Prod. J. 34(2): 57-61.

Kosmatka, S.H.; Panarese, W.C. 1992. Diseño y control de mezclas de concreto. Instituto Mexicano del Cemento y del Concreto, A.C. México D.F. 230 pp.

Maya-González, G. 1974. Materiales de construcción. McGraw-Hill. México, D.F. 212 pp.

Miller, D.P.; Moslemi, A.A. 1991. Wood-cement composites: Species and heartwood-sapwood effects on hydration and tensile strength. Forest Prod. J. 41(3):9-14.

Moslemi, A.A.; Lim, Y.T. 1984. Compatibility of southern hardwoods with Portland cement. Forest Prod. J. 34(7-8): 22-26.

Moslemi, A.A.; Garcia, J.F.; Hofstrand, A.D. 1983. Effect of various treatments and additives on wood- Portland cement- water systems. Wood Fiber Sci. 15(2): 164-176.

Ozawa, S.; Sasaya, T. 1988. Extractives of todomatsu Abies sachalinensis Masters IV. New cyclolignans containing a lactol ring from the wood of Abies sachalinensis. Mokuzai Gakkaishi 34(2): 169-175.

Sauvat, N.; Sell, R.; Mougel, E.; Zoulalian, A. 1999. A study of ordinary Portland cement hydration with wood by isothermal calorimetry. Holzforschung 53(1): 104-108.

Semple, K.E.; Cunningham, R.B.; Evans, P.D. 1999. Cement hydration tests using wood flour may not predict the suitability of Acacia mangium and Eucalyptus pellita for the manufacture of woodwool cement board. Holzforchung 53(3): 327-332.

Sha, W.; O'Neill, E.A.; Guo, Z. 1999. Differential scanning calorimetry study of ordinary Portland cement. Cem. Concr. Res. 29(9): 1487-1489.

Simatupang, M.H.; Lange, H; Kasim, A. 1992. Semimicro electrical conductivity method to trace the hydratation of $\beta$-gypsum hemihydrate in the presence of wood extractives of some tropical wood species. Holzforschung 46(4): 357-359

Simatupang, M.H., Lange, H.; Kasim, A.; Seddig, N. 1988. Influence of wood species on the setting of cement and gypsum. pp. 33-42, in Moslemi, A.A.; Hamel, M. P. 1989. International Conferance on Fiber and Particleboard Bonded with Inorganic Binder. Idaho, USA. 
Simatupang, M.H.; Sedding, N.; Habighorst, C.; Geimer, R.L. 1990. Technologies for rapid production of mineral-bonded wood composite boards. pp. 18-22, in Moslemi, A.A. 1991. Inorganic bonded wood and fiber composite materials: Proceeding of the 2nd International inorganic bonded wood and fiber composite materials conference. Idaho, USA.

Wei, Y.; Zhou, Y.; Tomita, B. 2000. Hydration behavior of wood cement-based composite I: Evaluation of wood species effects on compatibility and strength with ordinary Portland cement. $J$. Wood Sci. 46(4):296-302.

Willför, S.; Nisula, L.; Hemming, J.; Reunanen, M.; Holmbom, B. 2004. Bioactive phenolic substances in industrially important tree species. Part 2: Knots and stemwood of fir species. Holzforschung 58(6): 650-659.

Zhengtian, L.; Moslemi, A.A. 1985. Influence of chemical additives on the hydration characteristics of western larch wood-cement-water mixtures. 35(7-8): 33-43. 